\title{
SEXUAL DIMORPHISM IN RANA CURTIPES (JERDON)
}

\author{
S.V. Krishnamurthy ${ }^{1}$ and Katre Shakuntala ${ }^{2}$
}

' (Corresponding author) Department of PG studies and Research in Environmental Science, Kuvempu University, Jnana Sahyadri, Shankaraghatta, Sringeri, Karnataka 57745 I, India.

'Department of Zoology, Bangalore University, Jnana Bharathi, Bangalore, Karnataka 560056, India.

\section{Introduction}

Rana curtipes (Jerdon) is a common litter frog of the forests of Western Ghats, found abundantly during late premonsoon (May) through monsoons (June to September), but rarely encountered during other times of the year (Krishnamurthy, 1996). Hitherto, some information on the biology of this species is available (Rao, 1914; Inger \& Dutta, 1986; Sekar, 1990; Daniel \& Sekar 1989; Daniels 1992; Sunder Ram, 1993; Krishnamurthy \& Katre, 1993, 1997; Krishnamurthy, 1996), but information on sexual dimorphism is wanting. Although, sexually dimorphic characters, viz., tegumentory callosities of males, vocal sacs and colour dimorphism in commonly available anurans (Saidapur \& Nadakarni, 1975; Loft, 1984; Kasinathan \& Sriramalu, 1989) and femoral glands in Nyctibatrachus major (Krishnamurthy, et al., 1992) were detailed, these information are either touched upon the male characters or on their seasonality. However minute details of sex characters assisting in amplexus, particularly in hyloranids are not well documented. Considering this in this paper, we detail the sexually dimorphic external and osteological characters of male and female Rana curtipes. Further, this is the first report on the sexual dimorphism of this species.

\section{Materials and Methods}

A total of 186 adult frogs (57.129) were collected during June to October 1995-97 from the forests of Sringeri Taluk (Karnataka State). In each collection, morphological and morphometric parameters were recorded on the spot and after retaining a subsample, the rest of the collection was released back to their habitat. During August to November of each year amplecting pairs were recorded in the margins of slow moving waters. A few of such amplecting pairs were also collected for recording the morphological and morphometric details. In the laboratory, the subsamples and three amplecting pairs were sacrificed and skeletal prepartion was made using $2 \% \mathrm{KOH}$ solution and details recorded.

\section{Results and Discussions}

Most of the morphological characters and sexually dimorphic features of the species recorded in the present study are comparable with the earlier description of Sunder Ram (1993).

Received 20 February 1999;

Accepted 31 March 1999
Important sexually dimorphic characters of the species as recorded in the present observations are detailed in Table 1. During nonbreeding seasons the colouration remains similar in both males and females, while during breeding season the male in addition to thumb pad, develops two whitish-cream coloured spots on either sides of urostyle. Males possess an internal vocal sac with feeble vocalization during nonbreeding season, which will turn distinct with the onset of monsoon (breeding season). In females the vocal sacs are absent and not discernable. In size, as in other species of anurans, (Loft, 1984; Kasinathan \& Sriramalu, 1989), the females are larger (SVL 56.8 $+/-16.87 \mathrm{~mm}$ ) than males (SVL $46.8+/-14.25 \mathrm{~mm}$ ) and this character is also apparent amongst other morphometric characters (Table 2). The differences between male and female $R$. curtipes are also depicted in the skeletal details (Table 1). The ratio between the skull length, width, pelvic girdle and urostyle (as a percentage of SVL) to the average SVL shows smaller values in males than in females. However, an interesting feature of this species is in the minute detail of urostyle, which is slightly elevated distally. The ratio between the urostyle and average SVL in male and female are 1.82 and 2.05 respectively. This depicts that, the urostyle in male is smaller in size compared to the female. The amplexus is auxillary. During amplexus, the vent region of male is approximated with the elevated tip of urostyle of female, depicting the significance of this elevation as support to the amplecting male.

\section{References}

Daniel, J.C. and A.G. Shekar (1989). Field guide to the amphibian of western India. Part-4. J. Bombay nat. His. Soc. 86: 194-202.

Daniels, R.J.R. (1992). Geographical diştribution patterns of amphibians in the western Ghats, India. J. Biogeography 19: 521-529. Inger, R.F. and S.K. Dutta (1986). An overview of the amphibian fauna of India. J. Bombay nat. His. Soc. 83 (suppl): 135-146.

Kasinathan, S. and Sriramalu (1989). Reproductive strategy in amphibians. Super Power Press. Kollidam, Kerala. 180pp.

Krishnamurthy, S.V., Katre Shakuntala and S. Ravichandra Reddy (1992). Structure of femoral gland and habitat features of an endemic anuran Nyctibatrachus major (Boulenger). J. Indian Inst. Sci. 72: 385393.

Krishnamurthy, S.V. and Katre Shakuntala (1993). Amphibian fauna of Sringeri Taluk (Chikmagalur Dist. Karnataka) J. Indian Inst. Sci. 73: 443-452.

Krishnamurthy, S.V. (1996). Habitat features of amphibians in 
Table 1. Sexual dimorphism of adult Rana curtipes based on average values of total collections (Linear values are in millimeter and weights are in gram. The values in parentheses under the skeletal details are the ratio of respective parameters to the average snout-vent length, SVL)

\section{Parameter}

Male

Female

1. Body colouration

a) Non-breeding season

b) Breeding season
Similar to female

Two whitish-cream coloured spot on

either sides of urostyle
Similar to male

$--$

2. Size.

Average SVL

46.8

56.8

Maximum SVL

65.0

82.0

Average body weight

4.4

8.6

Maximum body weight

25.2

3. Skeletal details

(as \% of SVL)

Skull length

$37.87(1.23)$

$38.15(1.49)$

$34.84(1.34)$

$40.78(1.40)$

$31.81(1.47)$

$35.52(1.60)$

$25.75(1.82)$

$27.63(2.05)$

Urostyle length

Internal; Vocalization

feeble but distinct

Absent and not

discernable

during breeding season

Sringeri, Western Ghats, Zoos' Print 11(8): 2-6.

Krishnamurthy, S.V. and Katre Shakuntala (1997). Rana curtipes (Bicoloured Frog) Reproduction. Herp. Review 28(4): 200-201.

Loft, B. (1984). Amphibians, In: Marshall's physiology of reproduction, Vol. I. Reproductive cycle of vertebrates G.E. Lamming (Ed.), 4th ed. Pp 127-205.

Rao, C.R.N. (1914). Larva of Rana curtipes. Rec. Indian. Mus. 10: 265.

Saidapur, S.K. and V.B. Nadakarni (1975). Seasonal variation in the structure and function of testis and thump pad in the frog Rana tigrina (Daud). Indian J. Expl. Biol. 13: 432438.

Sekar, A.G. (1990). Notes on morphometry, ecology, behaviour and food of tadpoles of Rana curtipes, Jerdon 1853. J. Bombay nat. His. Soc. 87: 312-313.

Sundar Ram, M.J. (1993). Biology of Rana curtipes (Jerdon) Ph.D. Thesis, Bangalore University, 199pp.
Table 2. Average morphometric measurement of three amplectant pairs of Rana curtipes (Linear measures are in millimeter $+/-S . D$. and weight are in gram $+/-$ S.D.)

\begin{tabular}{lll}
\hline Parameter & Male & Female \\
\hline Snout-Vent length & $59.0+/-8.520$ & $81.0+/-1.414$ \\
Hind limb length & $80.67+/-11.467$ & $109.67+/-4.497$ \\
Head length & $15.67+/-6.018$ & $21.0+/-6.377$ \\
Body weight & $10.50+/-4.060$ & $24.4+/-2.070$ \\
Forelimb length & $36.33+/-5.436$ & $51.0+/-5.715$ \\
Femur length & $22.0+/-4.966$ & $28.67+/-1.247$ \\
Tibia length & $20.0+/-4.320$ & $29.33+/-1.699$ \\
Liver weight & $0.27+/-0.117$ & $0.453+/-0.136$ \\
Gut weight & $94.0+/-18.402$ & $140.66+/-9.977$ \\
\hline
\end{tabular}

